\title{
RECEPCJA OSMAŃSKIEGO SYSTEMU RZĄDÓW W PAŃSTWACH BAŁKAŃSKICH W XIX-XX WIEKU ${ }^{1}$
}

\author{
MIROSŁAW DYMARSKI
}

\begin{abstract}
Mirosław Dymarski, Recepcja osmańskiego systemu rzqdów w państwach bałkańskich $w$ XIX-XX wieku (The Reception of Ottoman system of rule in the Balkan states in the 19th-20th c.) .

The article identifies the key elements of the reception of Ottoman rule in the Balkan states in the 19th and 20th c. The character of the centralized regimes established in the Balkan states defined as sultanism, autocracy, and authoritarianism, resulting from the absence of democratic tradition and an underdeveloped political awareness and culture. A characteristic feature of the Turkish system was the position of relatively free peasants, very different from that in Europe. The feature characteristic of the Ottoman tradition which survived in the Balkans the longest, until the end of the 20th century, was violence as an intrinsic component of political life and power often changing hands as a result of violence, assassinations, murders, etc.
\end{abstract}

KEYWORDS: ottoman tradition, political culture, political regime, violence, social order

Balcanica Posnaniensia. Acta et studia, XXI, Poznań 2014, Wydawnictwo Instytutu Historii UAM, pp. 137-150, ISBN 978-83-63047-59-7, ISSN 0239-4278. Polish text with a summary in English.

Mirosław Dymarski, Instytut Politologii, Uniwersytet Wrocławski, ul. Koszarowa 3, 51-149 Wrocław, emdym@rubikon.pl.

Analiza osmańskiej spuścizny społecznej i politycznej na Bałkanach była i jest obiektem licznych studiów. Ze względu na stopień złożoności problemu oraz fakt, że społeczeństwa państw bałkańskich starały się jak najszybciej zrzucić dziedzictwo osmańskie, nie można wyprowadzić wniosków jednoznacznych. W podjętym temacie omówiona zostanie recepcja elementów osmańskiego dziedzictwa politycznego w systemie rządów w państwach bałkańskich po uzyskaniu niepodległości.

Wybitna badaczka dziejów Bałkanów Maria Todorova słusznie stwierdza, że różnice wśród bałkańskich społeczeństw wykluczają mówienie o jednej spuściźnie osmańskiej, ale można mówić o skupisku pewnych „ciągłości” już po secesji państw bałkańskich ${ }^{2}$. Trzeba unikać generalizacji i pamiętać o dużym międzyregionalnym zróżnicowaniu. Rodzą się pytania zarówno o bezpośredni, choć krótkotrwały, wpływ dziedzictwa osmańskiego na system rządów Bułgarii, Serbii, Grecji, jego kontynuację $\mathrm{w}$ formie społecznych postaw i relacji z własnym państwem, jak i o przykłady prze-

${ }^{1}$ Tekst powstał w ramach grantu finansowanego przez Narodowe Centrum Nauki UMO-2011/03/B/ HS3/01453.

${ }^{2}$ M. Todorova, The Ottoman Legacy in the Balkans (in:) Imperial Legacy. The Ottoman Imprint on the Balkans and The Middle East, ed. C. Brown, New York 1996, s.53. 
trwania w systemach politycznych państw bałkańskich ducha osmańskiej spuścizny. Należy bowiem pamiętać o tradycji oralnej, w której przechowała się przez pokolenia pamięć o osmańskiej tyranii, a materialne dowody obecności Turków na Bałkanach ciagle o nich przypominały (twierdze, meczety).

Podejmując zagadnienie dziedzictwa osmańskiego w systemie rządów, należy się skupić na tych, które można zdefiniować jako continuum, choć czas ich trwania był różny, ale jednocześnie mogą być efektem dłuższej tradycji i jej transmisji do następnych wieków przez już istniejące systemy. Należy jednak pamiętać, że proste odwzorowanie tureckiego systemu rządów mogło odbywać się w przedziale jednego pokolenia, góra dwóch. Pamięć ludzka odnosi się do obrazów i sytuacji utrwalonych, jednak w miarę upływu lat doświadczenia poprzednich pokoleń nie stanowią już punktu odniesienia.

Klimat społeczny na Bałkanach musiał sprzyjać trwaniu systemu rządów podobnego do osmańskiego, którego jednak większość mieszkańców krajów bałkańskich już bezpośrednio nie doświadczyła. Możemy zatem mówić o czasowym oddziaływaniu osmańskiego systemu rządów na losy wolnych państw bałkańskich, ale procesy nie były równoległe we wszystkich krajach, a ich odmienny przebieg był uzależniony od momentu uwolnienia się od tureckiej dominacji, a nie następowało to w tym samym czasie.

Jedną z cech osmańskiego systemu rządów była niespotykana w zachodniej Europie pozycja stosunkowo wolnego chłopstwa, która winna być identyfikowana jako turecka spuścizna, z powodu polityki, jaką stosowali władcy Turcji osmańskiej począwszy od XIV wieku. Zgodnie z islamskim prawem i praktyką ziemia zdobyta na „niewiernych” - w tym wypadku Bałkany - była w dyspozycji państwa, czyli de facto sułtana, zabezpieczona dla ich chłopskich użytkowników ${ }^{3}$. W ten sposób imperium osmańskie chroniło chłopa przed „możnymi”4. Turcy po podboju Bałkanów zachowali dotychczasowy system agrarny i w losie tych ludzi niewiele się zmieniło ${ }^{5}$, jako że do obowiązków sułtana należało traktowanie poddanych, ,życzliwie i sprawiedliwie", zgodnie z utrwaloną tradycją ${ }^{6}$. Chłopi odgrywali ważną rolę, tak wcześniej, jak i później. Z pozoru wydawać się może to porównanie za niewłaściwe, ale podobieństwa są istotne. Punktem wyjścia musi być pozycja władcy oraz tzw. klasy rządzącej. Osmanowie stworzyli, według jednej z teorii, idealną monarchię absolutną 7 .

3 J. Haldon, The Ottoman State and the Question of the Autonomy. Comparative perspectives (in:) New Approaches to State and Peasant in Ottoman History, ed. H. Berktay, S. Faroqhi, London 1992, s. 57.

${ }^{4}$ H. İnalc1k, The Middle East and the Balkans under the Ottoman Empire. Essay on Economy and Society, Bloomington 1993, s. 144.

${ }^{5}$ M. Marinković, The Shaping of the Modern Serbian Nation and of Its State under the Ottoman Rule (in:) Disrupting and Reshaping Early Stage of Nation-Building in the Balkans, ed. M. Dogo, G. Franzinetti, Ravenna 2002, s. 38.

6 P. F. Sugar, Southern Europe under Ottoman Rule 1354-1804, Seattle-London 1977, s. 33.

${ }^{7}$ H. İnalc1k, Meaning of Legacy (in:) Imperial Legacy. The Ottoman Imprint on the Balkans and The Middle East, ed. C. Brown, New York 1996, s. 20. 
Wytworzenie elity rządzącej w ich państwie było wypadkową prawa islamskiego oraz polityki sułtanów. Trzeba uwzględnić dwa założenia często podnoszone w studiach nad państwowym systemem osmańskim: 1) państwo nie chroniło stabilnej, tradycyjnej, warstwy tureckiej szlachty i w konsekwencji nie było tradycyjnej państwowej elity rządzącej, 2) brak pierwotnej własności ziemi w połączeniu ze znaczną pozycją niewolników w państwie, także pochodzących z devşirme, oznaczał, że nie istniała klasa arystokracji, jako ogniwa pośredniego pomiędzy przeważnie chłopską raja a państwem, uosabianym przez sułtana. Oznaczało to także, iż państwo uzyskiwało niezbędne produkty rolne bezpośrednio od chłopów przez swoich poborców, oni więc byli wytwórcami, byli niezbędni, nie zaś feudałowie, nie na nich bowiem spoczywał obowiązek zapewnienia żywności krajowi ${ }^{8}$.

Przeto imperium osmańskie było na swój sposób egalitarne, ze względu na istnienie stosunkowo wolnego chłopstwa oraz jedynie elity państwowej, rekrutującej się zarówno z tradycyjnej, lecz słabej politycznie warstwy szlachetnie urodzonych, jak i niewolników, promowanych przez sułtana, których rola w państwie osmańskim była bardzo znacząca. Do tej elity należy jeszcze zaliczyć askeri - wojskowych - jako jedyną pośrednią grupę społeczną między chłopstwem a sułtanem ${ }^{9}$. Może się to wydawać paradoksem, choć nie w państwie osmańskim, ale pobór niewolników powoli dostarczał Turcji osmańskiej establishmentu, nowej klasy rządzącej, chociaż tradycyjna klasa nadal rywalizowała z niewolnikami o pozycję społeczną. Egalitaryzm z czasów tureckich stał się również podstawą ładu społecznego w państwa bałkańskich.

Chłopi stanowili w państwach bałkańskich „sól ziemi”, byli interesariuszami polityki państwa i partii politycznych, stąd nowe władze przejęły od sułtana zasadę stosunku do chłopów, najliczniejszej warstwy społecznej. Była w niej kluczowa różnica między Bałkanami a Europą Zachodnią i Środkową. Dla sił politycznych w Serbii i Bułgarii chłopi stali się nie tylko celem zabiegów politycznych, ale byli również punktem odniesienia dla reform w kraju. Władza i klasa polityczna musiały liczyć się z faktem, że najliczniejszym wyborca jest chłop, ze wszystkim konsekwencjami jego postawy społecznej i kondycji duchowej. Bowiem paradoksalnie mieli oni głęboko zakorzeniony wrogi stosunek do zmian, co należy uznać za bezpośrednie dziedzictwo osmańskie. Imperium osmańskie przez wieki się nie zmieniało, zarówno w Anatolii, jak i na Bałkanach, co utwierdzało ludność w państwach bałkańskich, że stan niezmienny jest właściwy, służący społeczeństwu, niemal doskonały. Politycy zabiegali o poparcie chłopów starając się przekonywać, że ich tradycyjne wartości, właśnie dlatego, że są tradycyjne, nie są gorsze niż zmiany modernizacyjne w innych państwach Europy. Można być tradycyjnym, głęboko konserwatywnym, bo to nie umniejsza wartości, witalności i siły, a nawet ją wzmacnia przez wierność tym wartościom ludzie są przez to mniej ,grzeszni’ niż inne narody, bardziej od nich po ludzku war-

\footnotetext{
${ }^{8}$ Ten utrwalony pogląd jest kwestionowanych przez niektórych badaczy np. J. Haldon, op. cit., s. 54.

${ }^{9}$ Ibidem, s. 55.
} 
tościowi. Zrodziła się nawet specyficzna postawa, która emanowała strachem przed zmianami. Jeden z posłów serbskiej Partii Radykalnej na posiedzeniu Skupsztyny w 1903 r. stwierdził: „Wielu jest u nas piśmiennych. Póki w kraju było mniej piśmiennych póty chodził po nim Chrystus, a odkąd zyskaliśmy więcej piśmiennych spadła na nas klątwa" 10 .

Pojawienie się, więc, pierwszych idei modernizacyjnych wraz z przybyciem z zagranicy pierwszych elit serbskich (prečani kształceni głównie w Wiedniu i Paryżu) czy bułgarskich (wykształceni w Rosji) nie pociagnęło za sobą zmiany w nastawieniu społecznym, ba, zbudowało rodzaj muru między wąską elitą państwową a rzeszą niepiśmiennego chłopstwa na Bałkanach. Za fundamentalną, bowiem, wartość w wymiarze społecznym i politycznym uznawano patriarchalno-kolektywistyczny chłopski egalitaryzm. W piśmie „Nedeljni pregled” w 1908 r. Jovan Jovanović pisał, że „Srbija je demokratska zemlja bez nikakvih društvennih, ekonomskih i religijskih suprotnosti”, wyrażając tym powszechne polityczne myślenie ${ }^{11}$. Takie pojmowanie ładu społecznego było wcześniej ugruntowane polityką władz tureckich, gdyż bardziej gwarantowały one kolektywne prawa milletom (wspólnotom religijnym) niż jednostkom, stąd późniejsza budowa nowoczesnych państw, szczególnie w Serbii i Bułgarii koncentrowała się zdecydowanie bardziej na kolektywizmie niż na obywatelskości i prawach jednostki ${ }^{12}$.

Społeczne dziedzictwo osmańskie, a więc istnienie de facto wolnych chłopów, braku arystokracji, słabej burżuazja i obecności silnie scentralizowanego państwa było niewątpliwie ważne dla rozwoju systemu rządów w państwach bałkańskich po uzyskaniu przez nie niepodległości. Najbardziej rzucającym się w oczy elementem continuum, między imperium osmańskim a nowo powstałymi państwami bałkańskimi, i najpowszechniej wymienianym, są silne reżimy powstałe w państwach bałkańskich: sułtanizm, autokratyzm, autorytaryzm. Brak tradycji demokratycznych, niski poziom kultury politycznej, słabość prasy, jako czynnika opiniodawczego, w niewykształconym, ubogim społeczeństwie wszystko to sprzyjało rodzeniu się takich reżimów, jako naśladownictwa rządów tureckich lub im podobnych, w których rola społeczeństw była podrzędna.

Dominująca warstwa chłopska w państwach bałkańskich do pewnego stopnia determinowała poczynania władzy publicznej. Przywódcy polityczni musieli kierować się w swych poczynaniach interesem tej warstwy społecznej i formami propagandy dla niej zrozumiałymi, jeśli chcieli zachować przywództwo. Typ propagandy, jak i cele były oczywiście zindywidualizowane, dostosowane do miejscowych warunków. Dla ks. Miłosza Obrenovicia, pierwszego serbskiego władcy, chłopi byli zarówno celem jego polityki, jak i jej ofiarami. Miłosz nie znał innego systemu poza osmań-

10 O. Popović-Obradović, Kakva ili kolika država. Ogledi o političkoj i društvenoj istoriji Srbije XIX i XX veka, Beograd 2008, s. 330.[thum. autora]

${ }^{11}$ D. Stajonović, Recepcija ideala slobode jednakosti i bratsva (w:) Srbija u modernizacijskim procesima 19. i 20 veka. 3. Uloga elita, ed. L. Perović, Beograd 2003, s. 84.

12 Б. Стеваноић, Политичка култура и културни идентитети у Србији и на Балкану, Ниш 2008, s. 221. 
skim i był gotowy użyć wszelkich środków, by taki system realizować ${ }^{13}$. Polityczny rozwój Serbii powoli ewoluował, ale system rządów ks. Miłosza był wzorowany „na rządach osmańskich bez Turków"14. Jeden z jego wczesnych serbskich biografów wprost pisał, że ks. Miłosz przejął despotyzm od Turków. Urzędnicy w jego kancelarii posiadali tytuł „książęcy sług”, potrafił ich wybatożyć a nawet zabić, jeśli był z nich niezadowolony. Okrutny, bezwzględny wobec poddanych - ale wszak wolnych chłopów - traktował ich wedle wzorca sułtańskiego, bowiem zachowywał się jak „wschodni despota” czy „mały sułtan”15. Miłosz naśladował sułtana w stroju, zachowaniu, miał nawet rodzaj haremu, złożonego z dziewcząt z jego majątków ziemskich $^{16}$. Z jednej strony starał kreować się na obrońcę chłopów, dobrodzieja, z drugiej zaś łupił podatkami, które uważał - podobnie jak sułtan - za swoje osobiste dochody. Aby zdobyć pieniądze nie przebierał w środkach ${ }^{17}$. Jak pisał jeden z badaczy, czy były to posiadłości czy złote dukaty, jeśli tylko stanęły na jego drodze zagarniał je bez skrupułów, stąd m.in. ks. Miłosz był największym posiadaczem ziemskim w Serbii ${ }^{18}$. Jednak największy ówczesny przeciwnik polityczny ks. Miłosza, Toma Vučić Perisić, miał opinię równie złą: demagog, porywczy, intrygant, oszust, krwiopijca, rozbójnik $^{19}$. W podobny sposób jak Miłosz zachowywał się jego syn ks. Michał, który stworzył z kolei „,biurokratyczny despotyzm”, skupił władzę w swoim ręku, zlikwidował niezależność urzędników (po poprzednich rządach ustavobraniteli 1842-1858), a cechy takiego despotyzmu przetrwały do XX wieku ${ }^{20}$. Według Slobodana Jovanovicia ks. Miłosz i Michał reprezentowali ten sam typ władzy, byli absolutystami, którzy koncentrowali państwo we własnych osobach ${ }^{21}$.

Nie brak opinii, że reżim ustavobraniteli był równie autorytarny, oligarchiczny i orientalny, i organizował swoją władzę, jako ekskluzywna grupę, klikę urzędników, która „zarządzała” społeczeństwem, a nie rządziła w jego imieniu. Jej pomysłowość $\mathrm{w}$ dręczeniu ludzi - według jednego $\mathrm{z}$ badaczy - często przekraczała wzory tureckie ${ }^{22}$. Podobnie nieco zachowywali się kilkadziesiąt lat później król Milan Obrenović i jego syn Aleksander I, którzy dochody skarbu serbskiego trwonili na własne wydatki, nie zwracając uwagi na potrzeby społeczne i źródło, z którego pochodziły pieniądze. Współcześni obserwatorzy krytycznie oceniali także władcę Czarnogóry Mikołaja I.

${ }^{13}$ M. Marinković, op. cit., s. 43.

${ }^{14}$ M. Palairet, Rural Serbia Reshaped and Retarded 1739-1914, (in:) Disrupting and Reshaping, s. 80 .

15 В. Дворниковић, Карактерологија Југословена, Веоград 1939, s. 861-862.

${ }^{16}$ K.H. Karpat, Studies on Ottoman Social and Political History. Selected Articels and Essays, Lieden-Boston-Köln 2002, s. 462.

17 В. Стојанчевић, Милош Обреновић и његово доба, Београд 1966, s. 397; P. Pavlovich, The Serbians: the Story of a People, Toronto 1988, s. 126.

18 P. Pavlowich, The Serbians, s. 126.

19 В. Дворниковић, Карактерологија Југословена, s. 875-876.

${ }^{20}$ С. Јовановић, Друга влада Милоша и Михаила, Београд 1933, s. 467-468.

${ }^{21}$ Ibidem, s. 461.

${ }^{22}$ L. Despotović, Srpska politička moderna. Srbija u procesima političke modernizacije 19. veka, Novi Sad 2008, s. 61. 
Jego rządy były całkowicie poza kontrolą społeczną, a tytuł „gospodara”, pana, oddawał ducha relacji monarcha-poddani. Brytyjski dyplomata Henry Beaumont ze zgorszeniem wspomina wydatki z okazji jubileuszu pięćdziesięciolecia panowania Mikołaja I Petrovicia w 1910 r. Samo upiększenie stolicy państwa Cetinje kosztowało więcej niż roczne wydatki Czarnogóry na edukację ${ }^{23}$.

Czy elity serbskie, bułgarskie i greckie mogły wprowadzać sobie znane modele państwa do świadomości ludzi (chłopów), którzy znali państwo represyjne i kruchą symbiozę codziennego życia między ludem a takim państwem?

Jednakowoż wspólne dziedzictwo dało niekiedy bardzo różne wyniki w erze postosmańskiej. Przykładem może być pozycja polityczna chłopstwa, wysoka w niepodległej w Bułgarii, a jednocześnie relatywnie słaba w Serbii, chłopstwa raczej „,potulnego", przytłoczonego, a także w odniesieniu do czasu, kiedy chłopstwo to stało się polityczne aktywne w końcu XIX wieku. Należy zaznaczyć, że chłopstwo bułgarskie zdobyło swoją silniejszą niż w Serbii pozycję polityczną dzięki wydarzeniom w ostatnim ćwierćwieczu XIX wieku. Po krwawej wojnie rosyjsko-tureckiej 1877/78, utworzeniu Księstwa Bułgarskiego i ucieczce masy tureckich posiadaczy ziemskich, bułgarscy chłopi znacząco wzmocnili swój stan posiadania. Zagarnęli ziemię Turków i uzyskali przez to silniejszą pozycję niż w sąsiedniej Serbii. Ich aktywność polityczna stała się bardziej widoczna, a jej przejawem było utworzenie w 1900 roku Bułgarskiego Narodowego Związku Chłopskiego.

W zwierciadle osmańskiego systemu rządów odbijała się antypaństwowa postawa chłopstwa serbskiego, bułgarskiego i greckiego. Przetrwała wielowiekowa tradycja rewolt zdesperowanych chłopów, które miały charakter antyturecki, ale były też z ducha antypaństwowe, gdyż cały aparat ucisku miał charakter władzy państwowej, sułtańskiej. Wiązało się to z organizacją państwa osmańskiego, dość luźną generalnie, choć u jego steru była centralna monarchia absolutna. Jednak centrum było „daleko”, chłopi nie odczuwali jego siły ani bliskości, a choć ucisk podatkowy i represje żandarmerii tureckiej były bardzo dotkliwe, to państwa jako takiego nie znano. Pozwalało to trwać w formach zamkniętych, patriarchalnych, kolektywistycznych wspólnot. Kiedy więc nastało narodowe państwo centrum władzy zbliżyło się do ludu i jej surowość mogła być odczuwana bardziej dotkliwie, niż za czasów tureckich. Państwo kojarzyło się z zmianą (modernizacją - urzędy, policja, służba wojskowa, władza lokalna), tymczasem imperium osmańskie było konserwatywne, trwało unikając reform lub wprowadzało je z niechęcią i opóźnieniem, często pod przymusem, zatem trwanie w dotychczasowej organizacji życia społecznego uważano za rzecz naturalną, oczywistą i cenną, i w jakimś sensie państwo osmańskie było znane, choć obce. „Swoje”, narodowe państwo chłopi traktowali z taką samą wrogością i podejrzliwością, jak osmańskie. Brak chłopów w tworzeniu narodowego państwa to efekt anarchii dziedziczonej z okresu osmańskiego. Chłopi nie stosowali się do poleceń administracyjnych i igno-

${ }^{23}$ E. Roberts, Real of the Black Mountain. A History of Montenegro, London 2007, s. 278. 
rowali władze ${ }^{24}$. Dlatego w XIX wieku idea solidarności wspólnoty lokalnej, podzielana przez chłopów w Serbii, Bułgarii czy Grecji, miała dla nich większe znaczenie i sens niż idea wspólnoty narodowej czy państwowej ${ }^{25}$.

Postrzeganie państwa i władzy w społeczeństwach bałkańskich było obciążone okresem tureckiego panowania. Należy wyjść od tego, iż pojęcie państwa dla społeczeństwa żyjącego w bardzo tradycyjnej strukturze było czymś abstrakcyjnym i jedyną organizacją przymusu, jaką znali, była władza urzędników osmańskich, najczęściej poborców podatkowych, za którymi stała turecka żandarmeria. Ucisk podatkowy oraz częste i brutalne represje były najboleśniej odczuwanymi przejawami systemu rządów, głęboko zakorzenionymi w pojęciu władzy. Dlatego być może na rozwój ekonomiczny państw narodowych na Bałkanach poważnym cieniem, skutkującym powolnym wzrostem lub jego brakiem, kładł się charakter państwa tureckiego, które największą aktywność wykazywało w ściaganiu podatków i wymyślaniu nowych tytułów płatniczych, paraliżujących zwykłą ludzką działalność gospodarczą, dlatego życie chłopów na Bałkanach to bohaterstwo niewoli, bólu i umierania jak pisał jeden $\mathrm{z}$ autoró ${ }^{26}$. W tym miejscu warto może dodać, że dotychczasowego ducha społeczeństw podbitych przez Turków na Bałkanach charakteryzowała wyuczona przez wieki niemoc. Jedna z opinii trafnie wskazuje na istnienie czegoś nieokreślonego, co składało się na istotę postaw życiowych podbitej ludności - kismet (zrządzenie losu). Według tej niej niewiara w możliwość zmiany swego położenia redukowała postawy społeczne do minimum. W czasach i miejscu tak niepewnym jak Bałkany dominował instynkt przetrwania, który wzmagał wśród ludności postawę pasywności, a stosunek do władz balansował między pokorą a przebiegłością. Niewiara w to, że można odmienić swój los, ugruntowana przez przemoc i głoszoną wśród ludności Bałkanów istotę islamu, na długo zapewniła Turkom pokój społeczny, nie licząc buntów chłopskich, będących wyłącznie aktami rozpaczy a nie świadomym, zorganizowanym działaniem ${ }^{27}$. Vladimir Dvorniković, autor pomnikowych dzieł z zakresu socjologii i antropologii Słowian południowych, pisał ponadto o deslawinizacji i orientalizacji kulturowej mas na Bałkanach, jako konsekwencji kilkusetletniej niewoli tureckiej. Nasze żywotne siły tkwią w cierpieniu biedy i niedostatku - pisał Dvorniković ${ }^{28}$.

Cechą życia gospodarczego na Bałkanach była pasywność, niechęć do wykraczania poza prace i powtarzalne czynności zapewniające egzystencję. „Praca jest naszemu człowiekowi trochę obca. W pracy widzi on mękę i cierpienie, poniżenie (...), śmierć wszelkiego męstwa i bohaterstwa" - pisał Dvorniković ${ }^{29}$. Nie opłacało się więcej pracować, jeżeli owoce tej aktywności i tak zabierały władze osmańskie. Obojętność chłopów dla nowoczesnych zmian w rolnictwie korespondowała $\mathrm{z}$ ich postawą trwa-

24 K. Bozieva Abazi, The Shaping of Bulgarian and Serbian National Identities 1800-1900, Skopje 2007, 48-49

${ }^{25}$ Ibidem, s. 46-47.

${ }^{26}$ V. Dvorniković, Psiha jugoslovenske melanholije, Zagreb 1925, s. 34.

27 W. S. Vucinich, The Ottoman Empire. Its Record and Legacy, Princeton 1965, s. 120-121.

${ }^{28}$ В. Дворниковић, Карактерологија Југословена, s. 310.

${ }^{29}$ B. Despot, Filozofiranje Vladimira Dvornikovicia, Zagreb 1975, s. 126. 
nia w stanie niezmiennym, tradycyjnym, petryfikowanie istniejącego położenia, jako zadawalającego, będącego równowagą pomiędzy koniecznością zapewnienia sobie i rodzinie egzystencji a świadomością, że nadwyżkę ich pracy najchętniej zagarną „dzierżawcy podatków”, ludzie bezwzględni, do tego skłonni do nadużyć. Prowadziło to do rezygnacji chłopów z większej produktywności ${ }^{30}$. Progresywność podatków w stosunku do ludzi bardziej aktywnych, a przez to lepiej zarabiających, musiała być hamulcem do zwiększenia wydajności i pomnożenia produkcji. Przywykli mało pracować - głosiła jedna z opinii - bo owoce ich pracy zabierał ciemiężca, nie chcieli, więc, pomnażać bogactwa swoim prześladowcom. Utrwalał się kult prostoty, pozostawania w tym, co utrwalone, tradycyjne. Chłopi w Serbii, Grecji, Bułgarii, jak konstatuje jeden z obserwatorów, nawet po uwolnieniu się od dominacji tureckiej, odrzucali nowoczesne, racjonalne rozwiązania techniczne w rolnictwie, gdyż nakazywała im to „tradycja" ${ }^{31}$.

Na Bałkanach najsilniej być może w całej Europie odczuwało się proces tzw. długiego trwania, konsekwencję braku zmian przez stulecia i utrwalonego przez to konserwatyzmu. Wszelkie, więc, próby implementacji nowych rozwiązań w systemie politycznym, ekonomicznym czy społecznym napotykały czasem zdecydowany opór społeczny, a w większej części na obstrukcję, przeczekanie, zachowania typowe dla społeczności bezradnych wobec toczących się przemian i nie mających wpływu na działania władz. Pasywność społeczeństwa, wyuczona nie tylko wrogim osmańskim reżimem politycznym a także trwałością stosunków społecznych i warunków życia, nie mogła szybko przekształcić się w aktywność czy przynajmniej zainteresowanie sprawami dziejącymi się wokoło. Sceptycyzm i obserwacja poczynań nowych władz to najbardziej rzucające się w oczy codzienne postawy społeczne, jako transmisja recepcji systemu rządów osmańskich do nowych warunków.

Rodzenie się nowego systemu rządów (systemu państwowego) odbywało się w konwulsjach, które wzmacniała gwałtowna chęć zrzucenia zewnętrznych oznak tureckiego panowania, uczynienia jakiegoś „,nowego początku”, a niemożnością oderwania się od różnych przejawów dziedzictwa osmańskiego, tkwiącego w podświadomości, będącego rodzajem tradycji zakorzenionej na gruncie społecznym. Tworzenie nowych form władzy politycznej, instytucji politycznych odbywało się przez odwzorowywanie i adaptację europejskich modeli. Kontrastowało to jednak z mentalnością pierwszych przywódców politycznych tkwiących w tradycji tureckiej (a może po prostu bałkańskiej). W podobny sposób spoglądano na lud, który ze swym ,atawistycznym" strachem przed władzą oraz brakiem świadomości, że może być podmiotem a nie przedmiotem systemu rządów, pozwalał na petryfikowanie stanu dominacji i alienacji władzy. Bunty chłopskie były aktem rozpaczy a nie wiarą w moc ludu, który jest w stanie obalić złe rządy i stać się suwerenem.

${ }^{30}$ В. Дворниковић, Карактерологија Југословена, s. 326.

${ }^{31}$ А. Рајс, Чујте Сирби! Чувајте се себе, Београд 2008, s. 17-20. Archibald Reiss był profesorem kryminologii z Lozanny, który związał się Serbią jeszcze przed I wojna światową, kształcił później belgradzką policję i zmarł w Belgradzie w $1929 \mathrm{r}$. 
Cechą osmańskiego systemu rządów na Bałkanach, która zachowała najdłużej swoją żywotność, aż do końca XX wieku, była przemoc w życiu politycznym i gwałtowne zmiany władzy w wyniku użycia siły, zamachów, morderstw itp. Chcąc wymienić te choćby najważniejsze zabójstwa polityczne, można przedstawić cały przekrój wydarzeń we wszystkich niemal krajach. Już ks. Miłosz, aby utrzymać przywództwo wśród Serbów okresu powstania w Takowie w 1815 r., kazał zabić Kara Djordje, inicjatora i legendy powstania z 1804 r., który potajemnie przybył do kraju. Został on pojmany i poćwiartowany, a ks. Miłosz, chcąc zjednać sobie sułtana Mahmuda II, odesłał mu do Stambułu głowę Kara Djordja, co było zwyczajem okrutnym, hańbiącym, ale powszechnym na Bałkanach ${ }^{32}$. Sam ks. Miłosz został zmuszony do abdykacji i wygnany z kraju w roku 1839 . Jego następca i syn Michał zaledwie po trzech latach rządów także zmuszony do abdykacji. Aleksander Karadjordjević objął tron w 1842 roku wraz z reżimem tzw. ustavobranitjeli, ale i on w 1858 został zmuszony do ustąpienia i powrócił na tron sędziwy ks. Miłosz, ale tylko na dwa lata i po jego śmierci w 1860 zastąpił go ponownie ks. Michał, który skłonności absolutystyczne odziedziczył po ojcu, i stał się władcą coraz bardziej znienawidzonym. Zastrzelono go w Belgradzie w 1868 r. podczas przejazdu powozem przez park. Sprawców nie wykryto ${ }^{33}$. Jego następca książę, później król, Milan - „najgorszy spośród wszystkich despotów" - jak pisał współczesny brytyjski obserwator ${ }^{34}$ - został zmuszony do abdykacji, a jego syn ks. Aleksander Obrenović został zamordowany wraz z żoną Dragą podczas zamachu pałacowego w maju 1903 r. Mord ten doprowadził do poważnych zmian politycznych w kraju. Do władzy doszła dynastia Karadjordjeviciów i pozostała na tronie aż do upadku monarchii w Jugosławii. Imiennik ostatniego władcy z dynastii Obrenović, król Aleksander Karadjordjević zginął z kolei zamordowany w 1934 r. przez separatystów chorwackich podczas wizyty w Marsyliii ${ }^{35}$. W sierpniu 1860 r. został zamordowany w Kotorze, należącym wówczas do Austro-Węgier, ks. Daniło I Petrović, pierwszy świecki władca Czarnogóry, który zginął z rąk emigranta politycznego, członka jednego z plemion czarnogórskich. Przyczyną śmierci księcia był narastający od początku panowania despotyzm, arogancja i brutalność jego rządów ${ }^{36}$.

W Bułgarii najważniejszy mord polityczny to zabójstwo premiera Stefana Stambołowa, polityka, który odegrał ogromną rolę w ukształtowaniu nowoczesnej Bułgarii po roku 1878. Jednak Stambołow swymi autorytarnymi rządami, zmierzającymi do gwałtownej, przyspieszonej modernizacji państwa zaskarbił sobie wrogość wielu polityków, a przede wszystkim księcia Ferdynanda, władcy Bułgarii. Jego spektakularna śmierć, już po ustąpieniu z urzędu premiera, była przykładem skali nienawiści

32 С. К. Павловић, Србија. Историја иза имена, Београд 2004, s.45.

${ }^{33}$ F. Singleton, A Short History of the Yugoslav Peoples, Cambridge 1999, s. 95-96.

${ }^{34}$ V. Chirol sir, Serbia and Serbs, Oxford 1914, s. 7.

35 М. Екмечић, Дуго кретанње између клања и орања. Исорија Срба у новом веку (1492-1992), Нови Сад 2011, s. 199-200.

${ }^{36}$ E. Roberths, op. cit., s. 229; G.G. Arnakis, The Near East in Modern Times, vol. I The Ottoman Empire and the Balkan States to 1900, Austin-New York 1969, s. 254. 
w polityce bałkańskiej. Został przez prześladowców zaatakowany jadąc dorożka ulicą Rakowskiego w Sofii i posiekany szablą: odcięto mu dłonie i rozpłatano głowę. Według wielu ówczesnych opinii była to zemsta ks. Ferdynanda ${ }^{37}$. Sam Stambołow stwierdził krótko przed śmiercią, że książę Ferdynand ,jest moim intelektualnym zabójcą", co oznaczało, że go zniszczył w oczach bułgarskich elit ${ }^{38}$. Równie haniebny los spotkał innego bułgarskiego premiera Aleksandra Stambolijskiego, przywódcę chłopskiego, który rządził od wyborów w 1919 r., kiedy jego partia Związek Ludowy uzyskał większość w Narodnom Sobraniu. Jego polityka dyktatorskich rządów, niepohamowana energia, fanatyzm, narzucenie drakońskich metod uzdrowienia sytuacji kraju po klęsce w I wojnie światowej doprowadziły do fali wrogości przeciw niemu i zamachu stanu w 1923 r., który skończył się poniżającym zabójstwem bułgarskiego premiera ${ }^{39}$. Prześladowcy z kół wojskowych pojmali go w rodzinnej wsi i zamordowali, karząc mu wcześniej wykopać sobie grób, a następnie - zwyczajem bałkańskim - odcięli mu głowę i odesłali do Sofii w pudle po herbatnikach!40 Taka dekapitacja - oddzielenia ciała od woli (umysłu) - była najpełniejszym sposobem unicestwienia i poniżenia wroga, sposobem zaczerpniętym niewątpliwie $\mathrm{z}$ tradycji tureckiej. W Grecji król Jerzy I został zamordowany w Salonikach w 1913 r. przez anarchistę, a w 1928 r. w Belgradzie na posiedzeniu Skupsztyny został śmiertelnie postrzelony Stjepan Radić, przywódca Chorwackiej Partii Chłopskiej, główny opozycjonista w pierwszej Jugosławii. (A z najnowszych to bez wątpienia zabójstwo premiera Serbii Zorana Djindjicia, zamordowanego we współpracy członków policji i kryminalistów w $2003 \mathrm{r}^{41}$.) Można by mnożyć przykłady, w których terror indywidualny był powszechnie używaną metodą walki z władzą, przy tym z zastosowaniem często okrutnych form.

Innym przejawem przemocy była tzw. przemoc zlecona. Odnosi się to do działalności różnych oddziałów nieregularnych na Bałkanach i używania ich do osiagnięcia określonych celów politycznych. Począwszy od XV w. Turcy wykorzystywali bandy, które za żołd otrzymywany od władz osmańskich zastępowały wojska tureckie w utrzymaniu w ryzach ludność oraz innych uzbrojonych grup. Hajducy, ludzie, wokół których narosło wiele legend oraz interpretacji ich pochodzenia, składu społecznego itd., byli wykorzystywani do thumienia buntów lokalnych społeczności. Pod koniec XVII wieku po odrzuceniu Turków spod Wiednia, załamał się porządek na ziemiach podbitych w Europie Środkowej i narastał bandytyzm. Porta zaczęła zawierać takie porozumienia $\mathrm{z}$ hajdukami, jako siłą najemna, aby zapewnić minimalne bezpieczeństwo dla gospodarczej i administracyjnej działalności, i kontrolować jedne grupy

37 Д. Иванов, Лидерът Стамболов, София 2014, s. 109.

38 Д. Петков, Страници из спомените ми за Стамболова (w:) Стефан Стамболов като револуционер, общественик и државник, София 1921, s. 125.

39 R. Daskalov, Debating the Past Modern Bulgarian History: From Stambolov to Živkov, New York-Budapest 2011, s. 123.

40 R. J. Crampton, Aleksnadŭr Stamboliiski, London 2009, s. 113.

41 D. Pavićević, Memory, Trust and Fear in Post-Conflict Societas, „Southeastern Europe” 37 (2013), S. 182 . 
zbójników przeciwko innym ${ }^{42}$. Ta jednak epizodyczna rola hajduków na służbie tureckiej zatarła się w świadomości społecznej a zdominowała ją ich zupełnie inna rola przypisana im przez zbiorową pamięć. Od XVIII w. bowiem hajducy stali się legendarnymi wrogami państwa osmańskiego i przekształcili się w symbol osobistej odwagi i oporu przeciwko Turkom w walce o polityczną i religijną wolność ${ }^{43}$. Takim ich zapamiętała mitologia bałkańska ${ }^{44}$.

Inne grupy, jakie wykorzystywały władze osmańskie, to armatole (gr. armatoloi). Były to bandy zbrojnych, których przyjęto na turecki żołd do reprezentowania Turków i kontrolowania niedostępnych terenów na ziemiach greckich, również objętych działalnością rozbójniczą ${ }^{45}$. Najbardziej jednak znaną formą takiej ,zleconej przemocy" przez Turków, były oddziały baszybuzuków, przede wszystkim Czerkiesów, którzy stali się często forpocztą wojsk tureckich na terenach Bałkanów objętych buntami czy powstaniami. Czerkiesami nazywano wówczas wszystkie ludy muzułmańskie Kaukazu (Czerkiesów, Abchazów, Dagestańczyków, Czeczenów) wysiedlone w wyniku podboju tych ziem przez Rosję w latach 50. i 60. XIX w. Łącznie na Bałkany przesiedlono ok. 400 tys. Czerkiesów ${ }^{46}$, którzy były wykorzystywani do thumienia buntów ludności chrześcijańskiej, ale nader często zajmowali zwykłą grabieżą.

Stosowanie owej ,zleconej przemocy”, w konsekwencji doświadczeń osmańskich, stało się powszechne na Bałkanach. Na dużą skalę stosowały ją Grecja, Bułgaria i Serbia w walkach o tereny Macedonii, Tracji, Kosowa, Tesalii na przełomie XIX i XX wieku. Oddziały greckich andartów, bułgarskich komitów czy serbskich czetników prowadziły walkę z wojskiem i żandarmerią turecką, ale także pomiędzy sobą, by podporządkować sobie miejscową ludność i przygotować grunt pod inkorporację tych ziem do swoich ojczyzn. Transmisja prawa do przemocy do lokalnych grup dla osiagnięcia celu politycznego, stała się dziedzictwem post-osmańskim ${ }^{47}$. Permanentna walka oddziałów partyzanckich z Turkami, i pomiędzy sobą, doprowadziła do powszechnej wojny wszystkich ze wszystkimi. Władze państw bałkańskich były bezpośrednio lub pośrednio zaangażowane we wspieranie oddziałów serbskich, bułgarskich i greckich w Macedonii, gdyż ich działalność miała być drogą do realizacji narodowych celów ${ }^{48}$. Generalnie autorzy zajmujący się stosowanie ,zleconej prze-

42 J. Gledhill, C. King, Institutions Violence and Captive States in Balkan History (in:) Ottomans into Europeans. State and Institution Building in South-East Europe, ed. A. Mungi-Pippidi, W. van Meurs, London 2010, s. 251-252.

${ }^{43}$ W.S. Vucinich, The First Serbian Uprising 1804-1813, New York 1982, s. 365-367.

${ }^{44}$ K. Barkey, Bandits and Bureaucrats. The Ottoman Route to State Centralization, London 1997, s. 178.

45 Odysseus [C. Eliot], Turkey in Europe, London 1900, s. 77.

${ }^{46}$ M. Pinson, Ottoman Colonization of the Circassians in Rumeli after the Crimean War, „Études balkaniques" 1972, nr 3, s. 75.

47 J. Gledhill, C. King, op. cit., s. 250.

${ }^{48}$ I. Stawowy-Kawka, Macedonia w polityce państw batkańskich w XX wieku, Kraków 1993, passim. 
mocy", stwierdzają, że budowanie państwa przez stosowanie przemocy było częścią tradycji osmańskiej adoptowanej na gruncie państw bałkańskich ${ }^{49}$.

System rządów osmańskich wpłynął niewątpliwie na kształtowanie się polityki w państwach bałkańskich w XIX i XX wieku. Nie nastapiło oczywiście proste kopiowanie wzorów osmańskich, jako że elity w Serbii, Bułgarii, Grecji próbowały zrzucić zewnętrzne formy dziedzictwa tureckiego. Zwracano się ku rozwiązaniom politycznym mocarstwa europejskich, które wspierał walkę narodów bałkańskich o wolność.

Tradycję osmańską nie można uznać za całkowicie złą dla społeczeństw bałkańskich. Fundamentalnym argumentem będzie zachowanie w państwach bałkańskich statusu wolnego chłopstwa, choć politycznie zmarginalizowanego. Nie popadło ono w jakąś późną formę zależności feudalnej czy neofeudalnej, przeciwnie, chłopi byli esencją krajów bałkańskich, ze względu na całkowicie spłaszczoną strukturę społeczną. Z drugiej zaś strony nowe elity państwowe przyjęły dość lekceważący do nich stosunek (poza serbską Partią Radykalną Nikoli Pašicia), nie traktowały chłopa w pełni za podmiot, choć i on nie ułatwiał sytuacji swoją bierną, obstrukcyjną postawą i traktując swoje, narodowe państwo jak wroga.

Najbardziej wyrazistym śladami osmańskiej tradycji politycznej były reżimy autokratyczne (z uwzględnieniem różnic definicyjnych między nimi): od ks. Miłosza do króla Milana w Serbii, i od Stefana Stambołowa po cara Borysa w Bułgarii. Życie polityczne Bałkanów zatrute zostało tradycją okrutnej przemocy w życiu politycznym, niekiedy wręcz orientalnym okrucieństwem. To dziedzictwo prześladowało Bałkany do końca XX wieku, i z czasem stało się sobie właściwe - bałkańskie.

Tradycja osmańska odcisnęła piętno na społeczno-politycznym obrazie państw bałkańskich XIX, a w pewnym stopniu i XX wieku. System rządów formalnie oparty był na europejskich rozwiązaniach ustrojowych, ale w rzeczywistości nieefektywnych, ze względu na niski poziom rozwoju społecznego i takiż kultury politycznej. To z kolei sprzyjało praktyce lekceważeniu prawa i rozwojowi rządów autokratycznych, i w sposób niezamierzony, utrwalało w świadomości ludzi na Bałkanach przekonanie, że nie są Europejczykami a jakimś specyficznym kulturowym tworem pomiędzy orientem i Europą ${ }^{50}$.

49 Ottomans into Europeans. State and Institution Building in South-East Europe, wstęp, s. XII.

${ }^{50}$ R. Daskalov, Modern Bulgarian Society and Culture through the Mirror of Bai Ganio, „Slavic Review” 2001, vol. 60 (3), s. 531. 


\title{
THE RECEPTION OF OTTOMAN SYSTEM OF RULE IN THE BALKAN STATES IN THE 19TH-20TH C.)
}

\author{
MIROSŁAW DYMARSKI
}

Summary

The article identifies the key elements of the reception of Ottoman rule in the Balkan states in the 19th and 20th centuries. The most prominent element of the continuum and the one most often addressed in scholarship is the character of the centralized regimes established in the Balkan states defined as sultanism, autocracy, and authoritarianism, resulting from the absence of democratic tradition and an underdeveloped political awareness and culture. A characteristic feature of the Turkish system was the position of relatively free peasants, very different from that in Europe. The state did not protect the stable, traditional Turkish nobility and as a result there was no traditional ruling elite and the absence of traditional land ownership. This specific egalitarianism of the Ottoman period would become the foundation of social order in the Balkan states. As there was no native aristocracy or bourgeoisie, the peasants became the leading social class also in the Balkan states. Their attitudes, generally traditionally and deeply apprehensive of change, were likewise influenced by the Ottoman tradition. Over the centuries, the Turkish state had not changed and this profoundly affected the mentality of Balkan peasants which remained informed by social conservatism. At the same time, their attitudes towards the state as an institution were hostile and this also must be seen as a consequence of the influence of oppressive policies of the Ottoman state.

The feature characteristic of the Ottoman tradition which survived in the Balkans the longest, until the end of the 20th century, was violence as an intrinsic component of political life and power often changing hands as a result of violence, assassinations, murders, etc. There were many examples of individual terror which was commonly and often with excessive cruelty waged against the authorities in Bulgaria, Serbia, Greece.

Another important phenomenon was the so-called contracted violence. It refers to the activities of various irregular forces in the Balkans and using them to attain political goals. From the 15th century, the Turks would pay gangs of outlaws to substitute for Turkish regular troops in the task of controlling the local population and other armed groups. The hajduks, a class of people whose origin and social background have been the stuff of legend and subject to many interpretations, were initially hired to extinguish local rebellions. In the 17th century, the growing brigandage in the Balkans persuaded the Turkish authorities to commission the hajduks as mercenaries to provide some level of security to enable administrative and economic activity From the 18th century, in the Balkan folkloric tradition, the hajduk became a romanticized heroic figure defying unjust laws and fighting against the Ottoman authorities for the people's political and religious freedom. The armatolo $i$ were Greek irregular soldiers commissioned by the Ottomans to control areas in Greece and the bashi-bazouks in Bulgaria and Serbia.

The practice of resorting to hired violence continued in the Balkans as part of the Ottoman legacy and became quite common in the Balkan states. Mercenary units were commissioned by Greece, Bulgaria and Serbia fighting for territories in Macedonia, Thrace, Thessaly, Kosovo, in the late 19th -early 20th century. The Greek andarts, Bulgarian komits and Serbian Chetniks fought the Turkish army and gendarmerie and turned against one another to gain control over local populations and territories as a preliminary step before their prospective incorporation into respective nations. Researchers studying the problem of contracted violence generally agree that resorting to it in the process of nation building was part of the Ottoman tradition adapted in the Balkan states. 
